\title{
MENINGKATKAN AKTIVITAS DAN HASIL BELAJAR MATEMATIKA MATERI KPK DENGAN MODEL PEMBELAJARAN STUDENT FACILITATOR AND EXPLAINING BAGI SISWA KELAS VI
}

\author{
Yatimah $^{凶}$
}

SD 3 Tenggeles Mejobo Kudus

\begin{tabular}{|c|c|}
\hline Info Artikel & Abstract \\
\hline $\begin{array}{l}\text { Sejarah Artikel: } \\
\text { Diterima } 1 \text { Okt } 2019 \\
\text { Direvisi } 4 \text { Nov } 2019 \\
\text { Disetujui } 6 \text { Nov } 2019 \\
\text { Keywords: } \\
\text { Student facilitator, } \\
\text { Explaining, Least } \\
\text { common multiple. } \\
\text { Paper type: } \\
\text { Research paper }\end{array}$ & $\begin{array}{l}\text { The purpose of this study was to improve the activities and learning outcomes of the KPK mathematics } \\
\text { material through the student facilitator and explaining learning model and was carried out on Grade } \\
\text { VI students of Tenggeles Elementary School 3, Tenggeles Subdistrict, Kudus Regency Semester I, } \\
2016 / 2017 \text { Academic Year with a total of } 14 \text { students consisting of } 5 \text { male students and } 9 \text { female } \\
\text { students. The method used is classroom action research consisting of } 2 \text { cycles, each cycle consisting of } \\
4 \text { stages, namely planning, implementation, observation, and reflection. In cycles } 1 \text { and } 2 \text { the actions } \\
\text { taken with the student facilitator and explaining learning model. And the results, that there is an } \\
\text { influence of the use of student facilitator and explaining learning models on (1) Student learning } \\
\text { activities, an increase in student learning activities by 13, from the initial condition } 65 \text { to } 78 \text { in the } \\
\text { final condition; (2) Student learning outcomes, increasing student learning outcomes by 19, from the } \\
\text { initial condition } 61 \text { to } 80 \text { at the final condition. }\end{array}$ \\
\hline
\end{tabular}

(C) 2019 Universitas Muria Kudus

\footnotetext{
Alamat korespondensi:

Program Studi Pendidikan Matematika

Fakultas Keguruan dan Ilmu Pendidikan Universitas Muria Kudus

Kampus UMK Gondangmanis, Bae Kudus Gd. L. 1t I PO. BOX 53 Kudus

Tlp (0291) 438229 ex.147 Fax. (0291) 437198

E-mail: yatimahsp3@gmail.com
} p-ISSN 2615-4196

e-ISSN 2615-4072 


\section{PENDAHULUAN}

Matematika sebagai disiplin ilmu yang dapat meningkatkan kemampuan berpikir dan berargumentasi, memberikan kontribusi dalam penyelesaian masalah sehari-hari dan dalam dunia kerja, serta memberikan dukungan dalam pengembangan ilmu pengetahuan dan teknologi (Susanto, 2013:185). Matematika adalah ilmu yang membahas angka-angka dan perhitungannya, membahas masalah-masalah numerik, mengenai kuantitas dan besaran, mempelajari hubungan pola, bentuk dan struktur, sarana berpikir, kumpulan sistem, struktur dan alat (Hamzah, 2014:48).

Proses belajar merupakan rangkaian aktivitas siswa melalui pengalaman belajar (learning experience) untuk membentuk perilaku siswa. Keaktifan siswa selama proses belajar mengajar merupakan salah satu indikator adanya keinginan atau motivasi siswa untuk belajar (Anitah, 2009:2.13).

Model pembelajaran student facilitator and explaining adalah salah satu dari tipe model cooperative learning. Di dalam kelas kooperatif siswa belajar bersama dalam kelompokkelompok kecil yang terdiri dari 4-6 orang siswa yang sederajat tetapi heterogen, kemampuan, jenis kelamin, suku/ras, dan satu sama lain saling membantu. Tujuan dibentuknya kelompok tersebut adalah untuk memberikan kesempatan kepada semua siswa untuk dapat terlibat secara aktif dalam proses berpikir dan kegiatan belajar mengajar (Trianto, 2010:41). Model pembelajaran student facilitator and explaining adalah salah satu tipe cooperative learning yang menekankan pada struktur khusus yang dirancang untuk mempengaruhi pola interaksi peserta didik dan memiliki tujuan untuk meningkatkan penguasaan materi (Shoimin, 2014:183). Model ini bertujuan untuk meningkatkan penguasaan materi.

Anak usia SD sedang mengalami perkembangan pada tingkat berpikirnya. Ini karena tahap berpikir mereka masih belum formal, malahan para siswa SD di kelas-kelas rendah bukan tidak mungkin sebagian dari mereka berpikir masih berada pada tahapan pra konkret (Karso, 2012:1.4).

Peneliti melakukan sdudi pendahuluan di kelas VI SD 3 Tenggeles, Mejobo, Kudus, Tahun Pelajaran 2016/2017 semester I, materi KPK pada kondisi awal hasil belajar siswa rendah. Hal ini diunjukkan dengan nilai rata-rata hanya mencapai 61 di bawah KKM Matematika 65.
Hasil refleksi peneliti menunjukkan bahwa proses pembelajaran matematika masih belum menunjukkan hasil yang memuaskan. Upaya guru ke arah peningkatan kualitas proses belajar mengajar belum optimal. Bisa jadi karena guru dalam menyampaikan materi pelajaran lebih banyak dalam bentuk ceramah. Pembelajaran kurang dikemas secara menarik dan kurang memanfaatkan media. Sarana-prasarana yang dimiliki sekolah belum dimanfaatkan secara maksimal dalam menunjang pembelajaran matematika tersebut.

Penelitian terkait peningkatan hasil belajar sudah banyak dilakukan antara lain: (1) Suwito, (2013) melakukan penelitian dengan judul penelitian "Peningkatan prestasi belajar matematika materi FPB dan KPK melalui student facilitator and explaining (SFAE) di kelas VI SD Negeri 2 Sukorame Kecamatan Gandusari Kabupaten Trenggalek Semester I Tahun 2013/2014", (2) Sutikno, (2013) melakukan penelitian dengan judul "Penerapan metode student facilitator and explaining untuk meningkatkan keterampilan berpikir dan hasil belajar matematika siswa kelas IV MI Karangkonang".

Berdasarkan peenelitian-penelitian di atas peneliti kemudian memilih model pembelajaran student fasilitator and explaining, dengan model tersebut diharapkan dapat membantu meningkatkan hasil belajar siswa pada mata pelajaran matematika.

Model pembelajaran merupakan suatu pola yang dapat dijadikan pedoman oleh guru dalam penyajian materi. Model pembelajaran adalah pola yang digunakan sebagai pedoman dalam merencanakan pembelajaran di kelas maupun tutorial.

Model pembelajaran student fasilitator and explaining adalah model yang menjadikan siswa dapat membuat peta konsep atau bagan untuk meningkatkan kreativitas siswa dan prestasi belajar siswa. Model pembelajaran student fasilitator and explaining menjadikan materi yang disampaikan lebih jelas dan konkret karena berpusat pada apa yang dialami siswa, siswa akan lebih aktif dan berani untuk mengemukakan pendapatnya, sehingga tujuan pembelajaran dapat tercapai dengan maksimal yang ditandai adanya peningkatan hasil belajar siswa.

Berdasarkan identifikasi masalah di atas maka rumusan masalah dalam penelitian ini adalah: (1) Bagaimana peningkatan aktivitas belajar Matematika materi KPK bagi siswa kelas VI SD 3 Tenggeles semester I tahun 2016/2017 
setelah dibelajarkan dengan model pembelajaran student fasilitator and explaining?, (2) Bagaimana peningkatan hasil belajar Matematika materi KPK bagi siswa kelas VI SD 3 Tenggeles semester I tahun 2016/2017 setelah dibelajarkan dengan model pembelajaran student fasilitator and explaining.

Sementara tujuan penelitian ini adalah: (1) Untuk meningkatkan aktivitas belajar Matematika materi KPK bagi siswa kelas VI SD 3 Tenggeles semester I tahun 2016/2017 dengan model pembelajaran student fasilitator and explaining, (2) Untuk meningkatkan hasil belajar Matematika materi KPK bagi siswa kelas VI SD 3 Tenggeles semester I tahun 2016/2017 dengan model pembelajaran student fasilitator and explaining.

Kerangka berpikir penelitian tindakan kelas yang menerapkan model pembelajaran student facilitator and explaining seperti pada gambar di bawah ini.

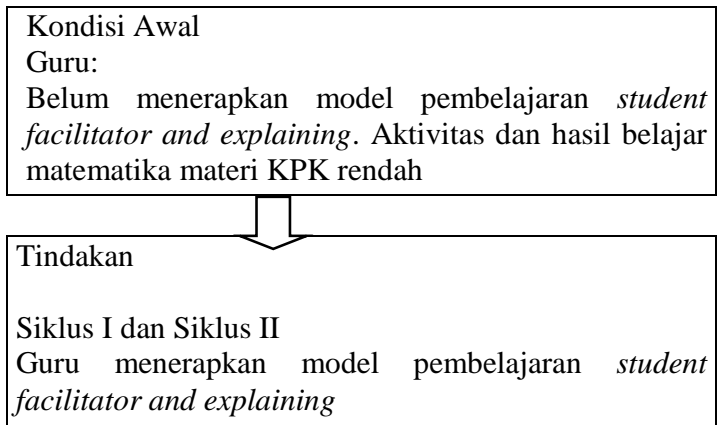

Kondisi akhir

Diduga penerapan model pembelajaran student facilitator and explaining dapat meningkatkan aktivitas dan hasil belajar matematika materi KPK bagi siswa kelas VI SD 3 Tenggeles, Mejobo Kudus semester I tahun 2016/2017.

Gambar 1. Kerangka Berpikir Penelitian Tindakan dengan Menerapkan Model Pembelajaran Student Facilitator and Explaining

\section{METODE PENELITIAN}

Penelitian tindakan kelas ini diawali dengan melakukan refleksi menentukan mata pelajaran yang hasil belajarnya rendah yang dilaksanakan pada bulan Agustus 2016. Setelah itu peneliti menyusun instrumen penelitian berupa Rencana Pelaksanaan Pembelajaran kondisi awal dan melaksanakannya pada bulan Agustus 2016.
Bulan Agustus dan September 2016 peneliti melaksanakan Siklus I dan II. Setelah itu pada bulan Oktober dan November 2016 peneliti mengumpulkan data dan menyusun laporannya.

Tempat penelitian ini adalah di SD 3 Tenggeles, Mejobo Kudus semester I tahun 2016/2017. Subjek penelitian berjumlah 14 siswa terdiri dari 5 siswa putra dan 9 siswa putri. Objek penelitian adalah mata pelajaran matematika materi KPK dikarenakan hasil belajarnya rendah.

Data dalam penelitian ini terbagi menjadi 2 yaitu data kualitatif dan data kuantitatif seperti tersebut di bawah ini: (1) Data kualitatif adalah data aktivitas belajar siswa, (2) Data kuantitatif adalah data hasil siswa.

Teknik yang digunakan untuk mengumpulkan data adalah : (1) Teknik Observasi. Teknik observasi digunakan untuk mendapatkan informasi tentang keaktifan siswa didalam mengikuti proses pembelajaran, dengan menggunakan lembar observasi yang telah dipersiapkan dan didiskusikan dengan pengamatan sebagai instrumen yang berisi indikator aktivitas belajar, (2) Teknik dokumentasi. Dalam peneliti dokumentasi penting adalah dokumentasi nilai tes formatif yang diambil pada tiap akhir pertemuan 2 siklus I dan II dengan kegiatan siswa melaksanakan tes formatif.

Penelitian ini divalidasi dengan: (1) Lembar observasi aktivitas belajar siswa berkolaborasi dengan teman sejawat sebagai pengamat, (2) Lembar tes formatif berupa soal yang harus dikerjakan siswa.soal pada tes formatif digunakan untuk mengukur apakah model pembelajaran yang digunakan sebagai alat untuk meningkatkan hasil belajar siswa berhasil ataukah gagal.

Dalam penelitian ini data yang dianalisis adalah: (1) data aktivitas belajar siswa kondisi awal, siklus 1, dan siklus 2 dengan teknik kualitatif, dianalisis menggunakan deskriptif komparatif dilanjutkan dengan refleksi, (2) data hasil belajar siswa dengan teknik kuantitatif dari data hasil belajar yang diambil dari kondisi awal, siklus 1, siklus 2. Data kondisi awal di daftar nilai.

Sebagai kriteria keberhasilan atau indikator pencapaian pembelajaran, peneliti menggunakan beberapa dasar yaitu menggunakan Kriteria Ketuntasan Minimal (KKM) pada mata pelajaran yang diterapkan oleh guru atau sekolah. KKM matematika di Kelas VI SD 3 Tenggeles Kecamatan Mejobo Kabupaten Kudus semester I tahun 2016/2017 adalah 65. Sehingga penelitian tindakan ini dikatakan berhasil jika: (1) Nilai ratarata aktivitas belajar skor $\geq 75$ pada kondisi akhir, 
(2)Nilai rata-rata hasil belajar siswa $\geq 65$ pada kondisi akhir.

Dalam penelitian ini prosedur penelitian menggunakan metode Penelitian Tindakan Kelas. Penelitian ini dilaksanakan sebanyak dua siklus dan tiap siklus terdiri dari 2 pertemuan, tiap pertemuan melalui 4 tahap yaitu: (1) perencanaan, (2) Pelaksanaan, (3) Pengamatan, (4) Refleksi. Berikut adalah prosedur penelitian tindakan kelas yang disajikan dalam Gambar 1 di bawah ini

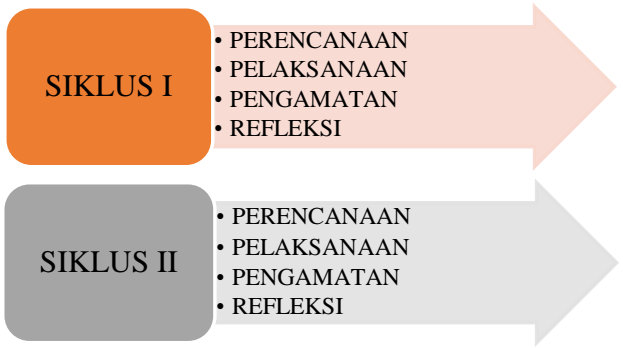

Gambar 2. Prosedur Penelitian Tindakan Kelas

\section{HASIL DAN PEMBAHASAN}

\section{Aktivitas Belajar Siswa}

Aktivitas belajar siswa pada kondisi awal dan kondisi akhir penelitian disajikan pada Tabel 1 dan Diagram 1 berikut.

Tabel 1. Aktivitas Belajar Kondisi Awal dan Kondisi Akhir

\begin{tabular}{cccc}
\hline No & Aspek Pengamatan & $\begin{array}{c}\text { Kondisi } \\
\text { Awal }\end{array}$ & $\begin{array}{c}\text { Kondisi } \\
\text { Akhir }\end{array}$ \\
\hline 1 & Aktivitas & 65 & 78 \\
\hline 2 & Indikator Kinerja & 75 & 75 \\
\hline
\end{tabular}

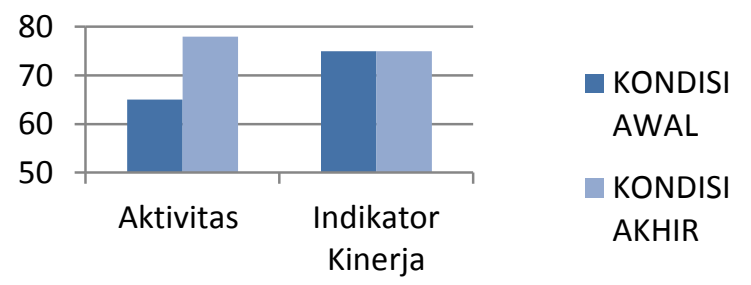

Diagram 1. Perbandingan Aktivitas Belajar Kondisi Awal, Kondisi Akhir

Berdasarkan Tabel 1 dan Gambar.1 di atas aktivitas belajar pada kondisi awal mencapai 65 dan pada kondisi akhir mencapai 78 terjadi kenaikan sebesar 13. Hasil refleksi peneliti menunjukkan bahwa proses pembelajaran matematika pada kondisi awal kebanyakan masih belum menunjukkan hasil yang memuaskan. Upaya guru ke arah peningkatan kualitas proses belajar mengajar belum optimal. Hal ini guru dalam menyampaikan materi banyak ceramah. Pembelajaran kurang dikemas secara menarik dan kurang memanfaatkan media.Sarana prasarana yang di sekolah tidak dimanfaatkan secara maksimal dalam pembelajaran matematika.

Pada kondisi akhir yaitu siklus I dan II peneliti memperbaiki proses pembelajaran dengan memilih model pembelajaran student fasilitator and explaining, menggunakan media pembelajaran. Pelaksanaan tindakan siklus I dan II dilaksanakan dengan dua kali pertemuan dengan langkah pembelajaran guru menyampaikan materi atau kompetensi yang ingin dicapai. Guru mendemonstrasikan atau menyajikan garis-garis besar materi pembelajaran. Memberikan kesempatan kepada siswa untuk menjelaskan kepada siswa lainnya, misalnya melalui bagan atau peta konsep. Hal ini bisa dilakukan secara bergiliran. Guru menyimpulkan ide atau pendapat dari siswa. Guru menerangkan semua materi yang disajikan saat ini. Menutup pembelajaran dengan tanya jawab. Setelah diadakan pengamatan, dapat diketahui bahwa terjadi peningkatan aktivitas belajar siswa pada kondisi awal dan kondisi akhir penelitian sebesar 13 poin. Aktivitas belajar kondisi awal mencapai 65 dan pada kondisi akhir telah mencapai 78. Hal ini menunjukkan bahwa siswa termotivasi untuk belajar. Sejalan dengan pendapat (Anitah, 2009:2.13) yang mengungkapkan bahwa keaktifan siswa selama proses belajar mengajar merupakan salah satu indikator adanya keinginan atau motivasi siswa untuk belajar

\section{Hasil Belajar Siswa}

Perbandingan hasil belajar siswa pada kondisi awal dan akhir disajikan pada Tabel 2 dan Diagram 2 berikut.

Tabel 2. Perbandingan Hasil Belajar pada Kondisi Awal dan Kondisi Akhir

\begin{tabular}{cccc}
\hline No & Kondisi & $\begin{array}{c}\text { Kondisi } \\
\text { Awal }\end{array}$ & Akhir \\
\hline 1 & Hasil Belajar & 61 & 80 \\
\hline 2 & $\begin{array}{c}\text { Nilai Hasil Belajar } \\
\text { Tertinggi }\end{array}$ & 70 & 100 \\
\hline 3 & $\begin{array}{c}\text { Nilai Hasil Belajar } \\
\text { Terendah }\end{array}$ & 50 & 60 \\
\hline 4 & KKM & 65 & 65 \\
\hline
\end{tabular}




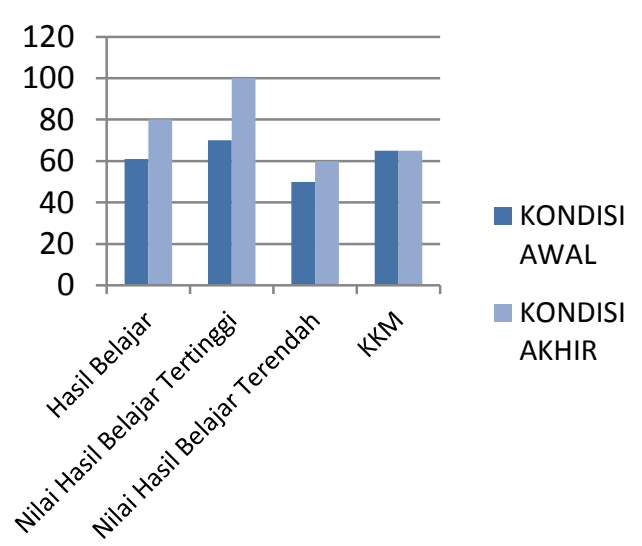

Diagram 2. Perbandingan Hasil Belajar Kondisi Awal dan Kondisi Akhir

Berdasarkan Tabel 2 dan Diagram 2 di atas hasil belajar siswa terjadi peningkatan 19 poin. Pada kondisi awa; 61 dan kondisi akhir 80. Peningkatan hasil belajar siswa terjadi setelah dibelajarkan dengan model pembelajaran student facilitator and explaining.

Model pembelajaran student facilitator and explaining merupakan rangkai penyajian materi ajar yang diawali dengan menjelaskan secara terbuka, memberikan kesempatan siswa untuk menjelaskan kembali kepada rekan-rekannya, dan diakhiri dengan penyampaian semua materi kepada siswa. Model pembelajaran student facilitator and explaining dapat melatih siswa untuk berani mengemukakan dan mengembangkan gagasan maupun ide yang mereka miliki.

Penelitian tindakan kelas yang peneliti laksanakan terdiri atas dua siklus. Siklus I dan II masing-masing dilaksanakan dalam dua kali pertemuan. Pada akhir pertemuan siklus yaitu pada pertemuan kedua, peneliti melaksanakan tes formatif untuk mengetahui hasil belajar siswa. Lembar tes formatif terdiri dari 10 soal pada siklus I dan siklus II 5 soal. Melalui penerapan model pembelajaran student facilitator and explaining terjadi peningkatan hasil belajar siswa pada tiap siklus. Hal ini sesuai dengan pendapat Huda (2014:229) kelebihan dari model pembelajaran student facilitator and explaining sebagai berikut: (1) membuat materi yang disampaikan lebih jelas dan konkret, (2) meningkatkan daya serap siswa karena pembelajaran dilakukan dengan demonstasi, (3) melatih siswa untuk menjadi guru, karena siswa diberi kesempatan untuk mengulang penjelasan guru yang telah di dengar, (4) memacu motivasi siswa untuk menjadi yang terbaik dalam menjelaskan materi ajar, (5) mengetahui kemampuan siswa dalam menyampaikan ide atau gagasan.

\section{SIMPULAN}

Berdasarkan hasil dan pembahasan di atas, dapat disimpulkan bahwa: (1) Aktivitas belajar siswa, peningkatan aktivitas belajar siswa sebesar 13, dari kondisi awal 65 menjadi 78 pada kondisi akhir, (2) Hasil belajar siswa, peningkatan hasil belajar siswa sebesar 19, dari kondisi awal 61 menjadi 80 pada kondisi akhir.

\section{DAFTAR PUSTAKA}

Anitah W. Sri, ddk. 2009. Strategi Pembelajaran di SD. Jakarta: Universitas Terbuka.

Hamzah, Ali dan Muhlisrarini. 2014. Perencanaan dan Strategi Pembelajaran Matematika. Jakarta: Raja Grafindo Persada.

Huda, Miftahul. 2014. Model-Model Pengajaran dan Pembelajaran. Yogyakarta: Pustaka Pelajar.

Karso, dkk. 2012. Pendidikan Matematika 1. Tangerang: Universitas Terbuka.

Shoimin, Aris. 2014. "68 Model Pembelajaran Inovatif dalam Kurikulum 2013”. Yoyakarta:Ar-ruzz Media.

Susanto. 2013. Teori Belajar Pembelajaran di Sekolah Dasar. Kencana Prenada Media Grup: Jakarta.

Sutikno. 2013. Penerapan metode student facilitator and explaining untuk meningkatkan keterampilan berpikir dan hasil belajar matematika kelas IV MI

Karangkonang.http://eprints.ums.ac.id/ 26995/9/2_PUBLIKASI_KARYA_ILM IYAH.pdf

Suwito. 2013. Peningkatan prestasi belajar matematika materi FPB dan KPK melalui student facilitator and explaining (SFAE) di kelas VI SD N 2 Sukorame Gandusari Kabupaten Trenggalek Semester I Tahun 2013/2014.http://jurnalpendidikanprofe sional.com/index.php/JPP/article/downl oad/145/pdf_85

Trianto. 2010. Model-Model Pembelajaran Inovatif Berorientasi Konstruktifistik: Konsep Landasan Teoritis, Praktis dan Implementasinya, Jakarta: Tim Prestasi Pustaka. 